\title{
Rola organów wladzy Królestwa Polskiego w pracach legislacyjnych nad narodowym prawem rzeczowym w latach $1815-1830$
}

\author{
Rolle der behördlichen Organe des Polnischen Königreichs \\ bei der gesetzgebenden Tatigkeit über das nationale Sachrecht \\ in den Jahren 1815-1830
}

1. Plany kodyfikacyjne u zarania Królestwa Polskiego. 2. Władza królewska i rząd a proces legislacyjny w Królestwie Polskim: 2.1. Król; 2.2. Namiestnik; 2.3. Rada Stanu; 2.4. Rada Administracyjna. 3. Rola Reprezentacji Narodowej $w$ procesie legislacyjnym; 3.1. Sejm. 4. Rola Komisji Rządowej Sprawiedliwości w procesie legislacyjnym. 5. Rola Komisji Prawodawczej i Deputacji Prawodawczych w procesie legislacyjnym. 6. Zakończenie.

1. Kodifikationspläne des frühen Polnischen Königreichs. 2. Macht des Königs und der Regierung einerseits und die Legislativverfahren im Polnischen Königreich andererseits; 2.1. König; 2.2. Statthalter; 2.3. Staatsrat; 2.4. Verwaltungsrat. 3. Rolle der Volksvertretung im Gesetzgebungsprozess; 3.1. Parlament (Sejm). 4. Rolle der Regierungskommission für Gerechtigkeit im Legislationsverfahren. 5. Rolle der Gesetzgebenden Kommission und der Gesetzgebendenabordnung in den Legislationsverfahren. 6. Abschuß.

1. Królestwo Polskie w latach $1815-1830$ było monarchią konstytucyjną. Polączone nierozerwalną unią personalną z Cesarstwem Rosyjskim ${ }^{1}$, w praktyce posiadało ograniczoną autonomię, która $\mathrm{z}$ czasem poszła $w$ kierunku ograniczenia liberalnych postanowień Konstytucji².

Ustawą zasadniczą określającą podstawy ustroju politycznego i społecznego Królestwa Polskiego, strukturę i kompetencję organów władzy oraz prawa i obowiązki ludności była Konstytucja podpisana przez cara Aleksandra I 27 listopada 1815 r. i ogloszona 24 grudnia tego roku.

Po klęsce Napoleona i upadku Księstwa Warszawskiego sprawa zmiany ustawodawstwa cywilnego w Królestwie Polskim wydawala się być nieunik-

\footnotetext{
${ }^{1}$ S. A sken azy, Rosja-Polska. 1815-1830, Lwów 1907, s. 63 i n.

2 W. M. Kozłow ski, Autonomia Królestwa Polskiego 1815-1832, Warszawa 1907, s. 86-88.
} 
niona. W kolach arystokratycznych planowano początkowo całkowite uchylenie Kodeksu Napoleona (KN - code civil) i procedury cywilnej francuskiej. Przede wszystkim ks. Adam Czartoryski, przed przybyciem do Księstwa, planowal szybkie zniesienie $\mathrm{KN}$ i zaprowadzenie w jego miejsce statutu litewskiego (trzeciego) i dawnych praw polskich. Zależało mu ponadto na wcieleniu do przyszlego Królestwa guberni zachodnich Cesarstwa, przy czym za niemożliwe uważal rozciągnięcie na nie instytucji kodeksowych Księstwa ${ }^{3}$.

Dopiero $\mathrm{z}$ czasem zdał sobie sprawę $\mathrm{z}$ tego, że sprawnie działającego „zarządu prawno-cywilnego" nie można znieść od razu. Otoczenie księcia, wywodzące się ze sfer urzędniczo-sądowych, także zdołało się przekonać o dużych walorach Kodeksu Napoleona. Ostatecznie zaś otaczający księcia prawnicy i politycy uznali, że KN należy zmienić - co najwyżej częściowo i „odpowiednio" uzupełnić.

W związku z tym, przedstawione Aleksandrowi I do podpisania 25 maja 1815 r. Zasady Królestwa Polskiego - autorstwa Czartoryskiego, nie zawierały już wzmianki o statucie litewskim ani o prawach polskich. Dowiadujemy się z nich, że: Prawa cywilne $i$ kryminalne, teraz będace - według $\S 8$ Zasad - nie przestanq obowiqzywać dopóty, dopóki nowe praw ksiegi, których ulożenie nakazaliśmy, nie uzyskaja sankcji $i$ ogloszenia ${ }^{4}$. Aleksander I zaakceptowal je 25 stycznia 1816 r. i nadal im moc tymczasowo obowiązującej ustawy oraz zaznaczyl, że Zasady powyższe Konstytucji Królestwa Polskiego slużyć beda za niezmienne prawidlo $i$ za instrukcje nowemu tymczasowemu Rzq̨owi tego krajus.

2.1. Szczególnie doniosły był udział króla w ustawodawstwie Królestwa. Sejm będący instancją Reprezentacji Narodowej składal się z króla i dwóch izb. Król zachowywal wylączne prawo inicjatywy ustawodawczej; do niego należało zwoływanie, odraczanie i zamykanie Sejmu (art. 87 Konstytucji Królestwa Polskiego; KKP). Mógł też zwołać Sejm nadzwyczajny, kiedy mu się to zdawać będzie (art. $88 \mathrm{KKP}$ ). Po uchwaleniu przez Sejm prawa lub budżetu udzielał sankcji, nadając projektowi moc prawa. Sankcja królewska miała moc równorzędną uchwałom Sejmu; w razie odmówienia sankcji projekt upadał (art. $105 \mathrm{KKP}$ ). Wszelkie rozkazy i postanowienia królewskie winny być zaświadczone podpisem stojącego na czele odpowiedniego wydziału

${ }^{3}$ S. A skenazy, Szkice $i$ portrety, Warszawa 1937, s. 374-377.

4. Bardach, M. Senkowska-Gluck, Historia Państwa i Prawa Polski, 1. III, Warszawa 1981, s. 226-227.

${ }^{5}$ M. R adziwi1ł, B. Winiarski, Królestwo Polskie. Dokumenty historyczne dotyczqce prawno-politycznego stosunku Królestwa Polskiego do Cesarstwa Rosyjskiego, Warszawa 1915, s. $71 \mathrm{i} \mathrm{n.}$ 
ministra - tzw. kontrasygnata, który był odpowiedzialny za zgodność tych aktów z Konstytucją i prawami (art. $47 \mathrm{KKP}$ ).

Monarcha mógł wydawać akty normatywne w celu wykonania ustaw o charakterze samoistnym bądź wykonawczym lub poza zakresem materii ustawowej; podobne uprawnienia w zakresie swojego pełnomocnictwa posiadal również namiestnik.

Monarcha niejednokrotnie włączał się do dyskusji nad kształtem przyszlego prawodawstwa narodowego $w$ Królestwie Polskim. Raz ten proces przyśpieszal, innym razem spowalniał albo zmieniał jego kierunek. Często $w$ sporach legislacyjnych powoływano się na poglądy $i$ autorytet cara $i$ nie zawsze wiernie je cytowano. Przede wszystkim Antoni Bieńkowski przy każdej niemal okazji twierdzil, że nigdy nie bylo wolq monarchy, aby kodeks cywilny francuski zostal calkowicie zmieniony, a wrecz przeciwnie, Aleksander I chcial tylko przystosowania tego kodeksu do warunków spolecznych $i$ zwyczajów istniejacych w Królestwie Polskim 6 .

Kodeks Napoleona (2281 art.) składal się ze wstępu i trzech ksiąg: I. O osobach, II. O majatkach i III. O różnych rodzajach wlasności $i^{7}$. Księga I obejmowała prawo osobowe, małżeńskie (ale bez majątkowego) i opiekuńcze; księga II dotyczyła głównie prawa rzeczowego, a więc obejmowała własność i dwa prawa rzeczowe ograniczone: użytkowanie $i$ służebności. Natomiast prawa rzeczowe zależne (zastaw, przywileje, hipoteka) zostały omówione w księdze III między zobowiązaniami, prawem spadkowym i małżenskim majątkowym, choć ukształtowane zostały jako prawa rzeczowe.

Jak wiadomo, Kodeks Napoleona powstal w zupełnie innej niż polska scenerii politycznej i odmiennych stosunkach społeczno-gospodarczych; zerwał z wszelkimi feudalnymi formami wlasności i jej ograniczeniami. $\mathrm{Na}$ ziemiach polskich bowiem w owym czasie powszechnie dominowały instytucje typowe dla epoki feudalnej, jak: prawa wylączno-okregowe, serwituty, własność podzielona. Były to instytucje nie znane kodyfikacji francuskiej, zatem KN zostal wtłoczony w rzeczywistość gospodarczą, spoleczną, polityczną i prawną, której nasi rodzimi obrońcy chcieli dać priorytet. Nie powinno więc dziwić, że polska myśl prawnicza rozwijała się $w$ tle toczących się

${ }^{6}$ Rada Administracyjna Królestwa Polskiego [dalej: RA], t. 8, s. 231: Sqqdze niemniej być potrzebnem ponowić uczynione już dawniej oświadczenie, że nigdy wolq najjaśniejszego nie bylo, by kodeks francuski we wszystkich zmienionym by mial być urzqdzeniach, owszem jego cesarsko królewska mość mieć chcialby te tylko wspomnianego prawa artykuly przepolszczonymi, to jest do zwyczajów narodu polskiego zastosowanemi byly, w którychby takowa zmiana za nieodzownq uznana zostala, a których by liczba znacznq być nie powinna.

${ }^{7}$ S. Płaza, Historia prawa $w$ Polsce na tle porównawczym, cz. 2: Polska pod zaborami, Kraków 1998, s. 48. Ten trójpodział formalnie nawiązywał do rzymskiej systematyki (personae, res, actiones). 
sporów wokół $\mathrm{KN}$, który oficjalnie byl jedynym obowiązującym źródłem prawa cywilnego. Chociaż tak naprawdę szereg stosunków społecznych i gospodarczych, typowych dla naszego kraju, pozostawał wówczas poza oficjalnie obowiązującym prawem.

Już w lecie roku 1817 , kiedy dyskutowano w Warszawie nad kierunkiem prac prawodawczych, nadeszła z Petersburga propozycja cara Aleksandra I, wyrażona $w$ odezwie ministra sekretarza stanu $z$ dnia 24 sierpnia/5 września $1817 \mathrm{r}$. Wynikało $\mathrm{z}$ niej, że prace nad ułożeniem nowego oryginalnego kodeksu cywilnego narodowego powinny zostać odłożone na czas bliżej nieokreślony ${ }^{8}$. Zalecał $w$ zamian szybkie przygotowanie nowych przepisów projektów częściowych w zakresie prawa cywilnego w następujących kwestiach: o urzędnikach stanu cywilnego, o sporach granicznych, o małżeństwie i rozwodzie oraz o hipotekach", a także kodeksu karnego wzorowanego na kodeksie austriackim. Szczególową organizacją komisji projektodawczej miał się zając namiestnik ${ }^{10}$.

Tak było też w dniu 19/31 lipca 1818 r. kiedy cesarz nadesłał własny projekt koncepcji prac prawodawczych. Polecił w nim, by Komisja Rządowa Sprawiedliwości (KRS) zajęła się tworzeniem kodeksu polskiego, przy zachowaniu $\mathrm{z}$ góry określonej systematyki pracy opartej na $\mathrm{KN}^{11}$, przy czym prace kodyfikacyjne miały być prowadzone przez pojedynczych redaktorów. Aleksander I aktywnie korzystał z przysługującej mu prerogatywy legislacyjnej, totéz gdy przed Sejmem w 1820 r. cały projekt księgi I i II k.c. narodowego, który na przełomie sierpnia i września 1820 r. przeszedł przez Radę Stanu, został odesłany do aprobaty królewskiej, Aleksander I wielce sie oburzyl zobaczywszy zamiast spodziewanej harmonijnej ksiegi praw, wyrywki poszczególnych artykulów $i$ postanowil tego prawa wcale nie przedstawiać Sejmowi ${ }^{2}$.

Cesarz Aleksander I, poprzez odezwę ministra sekretarza stanu Ignacego Sobolewskiego z $1 / 13$ października $1820 \mathrm{r}^{13}$, powolał ogólną Deputację

${ }^{8}$ Obraz Królestwa Polskiego w okresie konstytucyjnym, t. I: Raporty Rady Stanu Królestwa Polskiego z dzialalności rzqdu $w$ latach 1816-1828, oprac. J. Leskiewiczowa, F. Ramotowska, Warszawa 1984, s. 48-49.

9 J. J. Lita u r, Przyczynek historyczny do sprawy rewizji hypotek, „, Kwartalnik Prawa Cywilnego i Karnego" 1918, R. I (III), z. 1, s. 37; także W. Nowak ow ski, Rys historyczny ustaw hipotecznych z r. 1818 i 1825 , "Gazeta Sądowa Warszawska” 1888, t. 29, s. 481-486.

${ }^{10}$ H. Grynwaser, Kodeks Napoleona w Polsce, [w:] te ṅ̇e, Pisma, t. I, Wrockaw 1951, s. 164.

"I Rada Stanu, sygn. 200, s. 552-553. Zob. H. Gry n was er, Pisma, t. I, s. 118, przyp. 1

12 I Rada Stanu, sygn. 193, s. 160: Zmiany artykulów kodeksu cywilnego francuskiego i nowe dane tytuly z części II projektu do kodeksu cywilnego Królestwa Polskiego zredagowanego. Razem z powodami tych zmian i dodatków na stronie każdego artykulu w krótkości nadmienionymi. Przedstawione dnia 8 sierpnia $1820 \mathrm{r}$.

${ }^{13}$ I Rada Stanu, sygn. 200, s. 554: Minister sekretarz stanu ma honor udzielić namiestnikowi wole najjaśniejszego pana wypisana jak nastepuje. W Warszawie dnia $1 / 13$ października $1820 \mathrm{r}$. Podpisano J. Sobolewski. Zob. RA, t. 8, s. 321. 
Prawodawczą (zwaną też pierwszą). Jej treść, bynajmniej w części odnoszącej się do posłów, została odczytana na ostatnim posiedzeniu Sejmu 15 października $1820 \mathrm{r}^{14}$

We wrześniu $1823 \mathrm{r}$. stało się już oczywiste, że Deputacja nie zdąży przygotować przed Sejmem 1825 r. projektu księgi II i III k.c. narodowego. Taki obrót sprawy zaniepokoił cara. W dniu 27 listopada/9 grudnia $1823 \mathrm{r}$. nadeszła $\mathrm{z}$ Petersburga odezwa ministra sekretarza stanu gen. Stefana Grabowskiego i została skierowana do namiestnika. W zasadzie nakazywała Deputacji ograniczenie prac kodyfikacyjnych nad pozostałymi księgami KN (tj. ksiegga II i III k.c.) tylko do instytucji wymagających natychmiastowej zmiany i dyscyplinowala pozostałe organy do dalszej konstruktywnej pracy. Jej treść odczytana została też na posiedzeniu Rady Administracyjnej 24 grudnia 1823 r. $^{15}$ Poruszono $\mathrm{w}$ niej kilka spraw istotnych dla dalszego toku prac prawodawczych; zalecano calkowite zaniechanie prac nad kodyfikacją procedury cywilnej i karnej, aby Deputacja miala więcej czasu na zajecie sie kodeksem cywilnym narodowym ${ }^{16}$. Mimo ponagleń $\mathrm{z}$ Petersburga nie udało się wygotować księgi II k.c. narodowego na Sejm roku 1825.

W takiej sytuacji car Aleksander I odezwą ministra sekretarza stanu z 1/13 czerwca 1825 r. powolał nową Deputację Prawodawczą (zwaną też drugą). Deputacja ta miała się zajmować ulożeniem II i III ksiegi kodeksu cywilnego, tudzież kodeksu postepowania cywilnego $i$ karnego ${ }^{17}$.

Również Mikołaj I angażował się $\mathrm{w}$ prace legislacyjne nad prawem rzeczowym w Królestwie Polskim, o czym świadczy m. in. odezwa ministra sekretarza stanu z 12/24 marca $1829 \mathrm{r}^{18} \mathrm{Na}$ jej podstawie zawiesił on prace Deputacji nad księgą III k.c. i nakazal wykończyć najpierw księgę II k.c. i pilnie wymagane projekty częściowe ${ }^{19}$.

2.2. Namiestnik królewski był zastępcą króla w czasie jego nieobecności w Królestwie Polskim ${ }^{20}$; namiestnik miał stale przebywać w kraju. Obejmował funkcję z nominacji króla i mógł być przez niego odwołany (art. 5 KKP).

Zasadniczą funkcją namiestnika w czasie nieobecności króla było prezydowanie (przewodniczenie) w Radzie Stanu (art. $63 \mathrm{KKP}$ ). W czasie

${ }^{14}$ Dziennik posiedzeń Izby Poselskiej w czasie Sejmu Królestwa Polskiego 1820 r., przez Franciszka Obnińskiego, posia powiatu losickiego, sekretarza Sejmu, t. I i II, Warszawa 1820, s. 70-71.

15 RA, t. 11, s. $342-343$.

${ }^{16}$ I Rada Stanu, sygn. 200, s. 559-560.

${ }^{17}$ I Rada Stanu, sygn. 200, s. 564.

${ }^{18}$ I Rada Stanu, sygn. 200, s. 563.

${ }^{19} \mathrm{H}$. Gry nw as er, Pisma, t. I, s. 155.

${ }^{20}$ S. St a nk ie wi cz, Królestwo Polskie 1815-1863, [w:] Historia państwa i prawa Polski, t. 3: Od rozbiorów do uwlaszczenia, red. J. Bardach, M. Senkowska-Gluck, Warszawa 1981, s. $304-306$. 
obecności króla władza jego zostawała zawieszona (art. $71 \mathrm{KKP}$ ). Dekrety wydane przez namiestnika miały jedynie wtedy moc obowiązująca, gdy były wydane w Radzie Stanu i kontrasygnowane przez ministra, szefa departamentu (art. $68 \mathrm{KKP}$ ).

Namiestnik nie mógł działać samodzielnie; decyzje musiał podejmować na forum Rady Administracyjnej. W Radzie Administracyjnej namiestnik miał prawo wydawania aktów normatywnych oraz dosyć szerokie uprawnienia $w$ dziedzinie interpretacji przepisów prawa. Mógł on ustalać wiążącą wykładnię postanowień królewskich ${ }^{21}$, a w zakresie trybu ścigania przestępstw - interpretować nawet przepisy rangi ustawowej22.

Namiestnik przez cały okres Królestwa Polskiego brał udział w pracach prawodawczych, $w$ tym nad prawem rzeczowym. Funkcja jego polegała między innymi na wypełnianiu woli króla. Przykładowo: wobec zbliżającego się terminu zwołania Sejmu, namiestnik na wniosek Komisji Rządowej Sprawiedliwości 4 października $1817 \mathrm{r}^{23}$ powołal ośmioosobową Komisję Prawodawczą. Natomiast 11 sierpnia $1818 \mathrm{r}$. wydal tzw. „Zasady opracowania jednolitego prawodawstwa", w których zgodził się na wyznaczenie pojedynczych redaktorów ${ }^{24}$. Również postanowieniem namiestnika z 20 października $1818 \mathrm{r}^{25}$ skompletowano skład nowej Komisji i redaktorów: do kodeksu cywilnego przydzielono Antoniego Bieńkowskiego, do procedury karnej - Ksawerego Potockiego, do procedury cywilnej - Jana Nepomucena Wolickiego. Z kolei postanowienie namiestnika z 4 stycznia $1820 \mathrm{r}$. W zupełności uzależniło pracę redaktorów, głównie prawa cywilnego i procedury cywilnej, od KRS. Redaktorzy musieli na jej forum przedstawiać niemal każdą myśl Komisji.

Opierając się na odezwie z $1 / 13$ października 1820 r. Aleksandra I, namiestnik przystąpił do organizowania pracy powołanej Deputacji Prawodawczej. Również w 1825 r. kiedy to projekt kodeksu cywilnego narodowego miała przygotować powolana w tym celu przez Aleksandra I Deputacja Prawodawcza (druga), namiestnik mianowal z Rady Stanu trzech jej członków, tj.: Antoniego Wyczechowskiego, Franciszka Ksawerego Potockiego i Jana Hankiewicza ${ }^{26}$ - zaproponowanych przez Komisję Rządową Sprawiedliwości.

${ }^{21}$ RA, t. 4, s. 246-247, z 19 IV 1817 r.; t. 6, s. 191-192, z 19 V 1818 r.

${ }_{22}$ RA, t. 3, s. 313-314, z 12 XI 1816 r.; t. 12, s. 293-294, z 28 IX 1824 r.

23 Obraz Królestwa Polskiego..., t. I, s. 48-49.

${ }^{24}$ RA, t. 6, s. 427; zob. H. Grynwasser, Pisma, t. I, s. 167.

${ }_{25}$ RA, t. 6, s. 312 i 427 . Zob. H. G r y n waser, Pisma, t. I, s. 118, przyp. 2.

${ }^{26}$ I Rada Stanu, sygn. 200, s. 515. Komisja Rządowa Sprawiedliwości do namiestnika, w dniu 16 XI 1820 r.: Widzqc, że tu rzecz idzie o dogodzenie dwu celom, tj. o przepolszczenie kodeksu i jego zastosowanie, pragnelaby Komisja przestać na tym, co jest pilniejsze, tj. na zastosowaniu. Większość jednak czlonków Deputacji uniesiona gorliwościq pragnie dogodzic obydwu celom, upatruje nawet pilnq potrzebe w polqczeniu tych prac, ażebyśmy mieli ksiegi praw zupelnie narodowe. Zob. H. G r y n w ser, Pisma, t. I, s. 169 
Tak więc namiestnik głównie wykonywał wolę monarchy, zajmując się w pracach prawodawczych realizacją planów kodyfikacyjnych, przede wszystkim cara Aleksandra I.

2.3. Instytucją odgrywającą dużą rolę w procesie legislacyjnym była Rada Stanu; służyła ona ograniczaniu roli parlamentu, którego funkcje ustawodawcze częściowo przejmowała.

W Królestwie Rada Stanu dzieliła się na Zgromadzenie Ogólne oraz Radę Administracyjną (art. $65 \mathrm{KKP}$ ). Oznaczało to dość sztuczne połączenie Rady Stanu $z$ rządem, gdyż Rada Administracyjna Królestwa odpowiadała w dużym stopniu Radzie Ministrów Księstwa.

Zakres kompetencji Rady Stanu i tryb jej funkcjonowania określone byly przez Ustawe Konstytucyjną ${ }^{27}$, Statut Organiczny dla Rady Stanu z 19 listopada/1 grudnia $1815 \mathrm{r}^{28}$, oraz wydany równocześnie dekret Aleksandra I w sprawie organizacji wewnętrznej Ogólnego Zgromadzenia Rady Stanu $\left(\right.$ OZRS) ${ }^{29}$.

Ogólne Zgromadzenie RS z założenia miało odegrać poważną rolę w procesie legislacyjnym, gdyż art. 73 KKP wyraźnie mówil, że wszelkie ważniejsze projekty postanowień króla i namiestnika, jak również projekty ustawodawcze powinny być przedmiotem jego rozpoznania. Ogólnie rzecz biorąc, w dziedzinie legislacji dawało się zauważyć coraz mniejszy udział OZRS. W 1830 r. komisje Senatu miały wszelkie podstawy, by skarżyć się na to, że wydano kilka postanowień tyczqcych sie z bliska już to bezpieczeństwa osobistego, już wlasności prywatnej bez wysluchania zdania Ogólnego Zgromadzenia Rady. Chciały wnosić $\mathrm{w}$ związku $\mathrm{z}$ tym o zagwarantowanie, że żaden projekt jakiegokolwiek postanowienia pod odpowiedzialnościa ministrów nie może być panujacemu podany, ani przez Rade Administracyjnq uchwalony, bez poprzedniego rozbioru w Ogólnym Zgromadzeniu Rady Stanu ${ }^{30}$. Samo OZRS również $w$ pewnym stopniu przyczyniło się do ograniczenia swojej roli w legislacji nie tylko przez wadliwe funkcjonowanie, ale również przez uznanie, iż ,sprawy normatywne”, jako bardziej właściwe administracji, powinny być rozpoznawane wyłącznie przez Radę Administracyjną ${ }^{31}$.

W zakresie czynności prawodawczych Zgromadzenie Ogólne, a więc Rada Stanu w pełnym składzie, "rostrząsało i układało" wszelkie projekty „praw i urządzeń, ogólu kraju tyczących się" (art. 73 KKP). Projekty takie były wnoszone pod obrady Zgromadzenia Ogólnego $z$ reguły przez namiestnika, po uprzednim uchwaleniu przez właściwą komisję rządową. $Z$ wnioskiem

\footnotetext{
${ }^{27}$ Dziennik Praw Królestwa Polskiego 1815-1816 [dalej: DPKP], t. I, nr 1, 1815-1816.

28 DPKP, t. I, nr 4, 1815-1816.

29 Loc. cit.

30 Rkps nr 5253, k. 237, [w:] Biblioteka Czartoryskich w Krakowie.

31 I Rada Stanu, sygn. 414, s. 313.
} 
o „roztrząsanie” mógł wystąpić także sam król, jak i naczelnik wydziału. Dyskusja i głosowanie (wotowanie) nad projektem prawa były jawne (głośne). Uchwały Zgromadzenia Ogólnego zapadały większością głosów, zaś równość zdań uważano za przyjęcie projektu (art. $102 \mathrm{KKP}$ ).

Postanowienia OZRS wymagały potwierdzenia przez króla lub namiestnika (art. $75 \mathrm{KKP}$ ). Po decyzji króla o wniesieniu uchwalonego przez Radę Stanu projektu na porządek dzienny Sejmu, z projektem zapoznawała się odpowiednia komisja sejmowa. W razie zastrzeżeń komisja ta odbywała naradę (konferencję) z komisją rządową, która była autorką projektu, i przy udziale odpowiedniego referendarza stanu. Jeżeli zachodziła rozbieżność poglądów, to komisja kierowała projekt $\mathrm{z}$ propozycjami zmian do Rady Stanu, która podejmowala ostateczną decyzję i podawała gotowy projekt królowi do akceptacji. Rada Stanu wnosiła wreszcie, z rozkazu królewskiego, projekt ustawy do Sejmu.

Ogólne Zgromadzenie RS nie posiadało inicjatywy ustawodawczej i wobec tego mogło rozpatrywać tylko te projekty, które przedstawił mu monarcha - w praktyce namiestnik. Rola OZRS w procesie legislacji zależała wyłącznie od woli monarchy i namiestnika, poza tym tak znaczną liczbę ważnych projektów wydawano bez opinii OZRS.

Członkowie OZRS wchodzili również przez cały okres Królestwa Polskiego w skład cial prawodawczych, tj.: Komisji Prawodawczej powołanej w 1817 r. oraz obu Deputacji Prawodawczych. Mianowicie w 1825 r. w składzie Deputacji Prawodawczej (pierwszej) utworzonej przez Aleksandra I w 1820 r. znalazło się - spośród członków Rady Stanu zaproponowanych przez KRS i mianowanych przez namiestnika - trzech czlonków, wpływowych zwolenników utrzymania KN: Antoni Wyczechowski, Franciszek Ksawery Potocki i Jan Hankiewicz ${ }^{32}$. Wyżej wymienieni zostali przez namiestnika na posiedzeniu Rady Administracyjnej 16 czerwca 1825 r. (na mocy odezwy cesarskiej z $1 / 13$ czerwca 1825 r.) powołani do składu drugiej Deputacji Prawodawczej ${ }^{33}$.

Rada Stanu brała aktywny udzial w pracach nad prawem rzeczowym również jako organ. Mianowicie już w trakcie dyskusji w Radzie Stanu (maj 1819 r.) ujawniła się powszechna niechęć do poważnych zmian w KN. Projekt planu kodeksu cywilnego narodowego przygotowany przez Antoniego Bieńkowskiego wraz z opiniami Sądu Najwyższej Instancji i Komisji Rządowej Sprawiedliwości w dość nieprzychylnej formie zreferował 12 i 21 maja 1819 r. Antoni Wyczechowski ${ }^{34}$. Dlatego też Rada Stanu ostatecznie (27 ma-

32 Zob. przyp. 26.

${ }^{33}$ RA, t. 13, s. 143: Odezwa ministra sekretarza stanu donoszaca, iz cesarz postanowil utworzyć powtórnq Deputacje do ukladania projektów do praw i upowaznil nas do wyznaczenia w tym celu czlonków Rady Stanu, sam zaś wyznaczyl czlonków tejże Deputacji z grona izb sejmowych.

34 I Rada Stanu, sygn. 193, s. 107. 
ja 1819 r.) odrzuciła plan Bieńkowskiego i w dołączonej doń Instrukcji polecono mu trzymać się ściśle porządku kodeksu dotychczasowego (KN) i stosować się do wyżej określonych zasad ${ }^{35}$. Instrukcja opracowana przez Rade Stanu ograniczała pracę Bieńkowskiego w zasadzie do wąskiego zakresu - tj. do przystosowania kodeksu francuskiego do warunków spolecznych $i$ ekonomicznych Królestwa Polskiego i uzupelniania go zmianami koniecznymi ${ }^{36}$.

W dniu 7 kwietnia 1829 r. minister sprawiedliwości I. Sobolewski przedstawił Radzie Administracyjnej projekt całej księgi II k.c. narodowego, a ta przesłała go do dyskusji w OZRS, która trwala z przerwami ponad siedem miesięcy, tj. od 24 kwietnia 1829 r. do 7 grudnia 1829 r. Do udziału w niej zostali również zaproszeni członkowie Deputacji Prawodawczej - redaktorzy projektu ${ }^{37}$.

W sumie OZRS w przedmiocie dyskusji nad księgą II k.c. odbyło osiem posiedzeń, w czasie których projekt poddano druzgocącej krytyce. Na wstępie odrzucony został projekt do tytułu II księgi II k.c. $O$ dzierżeniu $i$ posiadaniu $u^{38}$. Dość szybko wytworzyła się w Radzie Stanu - zresztą pod przewodnictwem członków Komisji Rządowej Sprawiedliwości, tj. M. Woźnickiego, A. Wyczechowskiego i J. Hankiewicza - grupa opozycyjna wobec projektów Deputacji. W wyniku takiego rozwoju wypadków praca Deputacji była najwyraźniej marnowana przez powrót do artykułów kodeksu francuskiego. Ostatecznie OZRS (15 czerwca 1829 r.) podjęło decyzję o zaprzestaniu prac nad ułożeniem całej księgi II k.c. narodowego.

Zwolennicy prac całościowych podjęli jeszcze jesienią 1829 r. próbę zmiany decyzji OZRS, które w czasie trzech kolejnych posiedzeń w dniach 25,27 i 30 listopada $1829 \mathrm{r}^{39}$ zajęło się systematycznym rozbiorem tytułu III $O$ wlasności księgi II k.c. - od art. 592 do 612 . Jednak Zgromadzenie, „,po dawnemu", celowo obalało po kolei artykuły projektu i na ich miejsce przywracało artykuły $\mathrm{KN}$, wobec czego Deputacja zrezygnowała ze swojej dotychczasowej koncepcji prac kodyfikacyjnych, zgodzila się na zawieszenie systematycznego rozbioru księgi II k.c. i podjęcie prac nad zmianami częściowymi.

Nie ulega wątpliwości, że Deputacja została zmuszona do podjęcia takiej decyzji „dywersyjnym" działaniem OZRS. Wydaje się, że zadecydował o tym glos A. Wyczechowskiego. Zatem od dnia 1 grudnia

${ }^{35}$ Ibidem, s. 122.

36 Ibidem, s. 124.

${ }^{37}$ Il Rada Stanu, sygn. 51, s. 32. Zob. J. J. Lit a ue r, Materialy do rewizji kodeksu cywilnega, t. I: Ksiega II kodeksu cywilnego. Projekty Deputacji Prawodawczej $i$ Rady Stanu Królestwa Polskiego, Warszawa 1918, s. 70 i n.

${ }_{38}$ J. J. Lit a u e r, Materialy..., s. 65.

39 RA, t. 17, s. 614 . 
1829 r. Deputacja weszła w okres częściowych zmian w prawodawstwie Królestwa Polskiego; miała, bez zbędnej zwloki, obowiązek wnoszenia opracowanych projektów, po kolei, na forum OZRS, w celu dalszej dyskusji $^{40}$.

W okresie od 1 grudnia 1829 r. aż do zwolania Sejmu 24 maja 1830 r. Deputacja $w$ szybkim tempie przygotowała i wniosła pod obrady OZRS projekty aż siedmiu ustaw częściowych, tj.: o propinacji, o własności podzielonej, o rzekach spławnych i drogach publicznych, o prawach wyłącznookręgowych (zwanych też iura bannaria), o aktach legitymacyjnych, o służebnościach pastwiskowych $\mathrm{i}$ leśnych ( $w$ tym o prawie wrębu) oraz o zmianie przepisów prawa hipotecznego $w$ postępowaniu spadkowym ${ }^{41}$. Tak więc OZRS brało aktywny udział $w$ pracach nad przygotowaniem narodowego prawa cywilnego, a w szczególności prawa rzeczowego.

2.4. Konstytucja Królestwa Polskiego nie określała kompetencji Rady Administracyjnej, gdyż Rada winna być jedynie forum, na którym namiestnik mial podejmować decyzje $w$ formie postanowień. Zadania Rady Administracyjnej były złożone i nie dość jasno sprecyzowane. Jej kompetencje można podzielić na legislacyjne (przygotowanie, stanowienie i zatwierdzanie przepisów prawnych), finansowe (przygotowywanie, zatwierdzanie i wykonywanie budzetu), kierowniczo-koordynacyjne (bezpośrednie kierowanie działalnością administracji), administracyjne (podejmowanie decyzji w określonych sprawach indywidualnych) i polityczne ${ }^{42}$. Tryb dzialania Rady Administracyjnej szczegółowo został określony przez Statut Rady Stanu oraz organizację wewnętrzną samej Rady.

Rada Administracyjna mogła działać w sposób kolegialny, mimo że nie przewidywała tego Konstytucja Królestwa Polskiego ani Statut Rady Stanu. Jednakże Rada nie mogła stanowić kolegium uchwałodawczego, była więc radą namiestnika i monarchy.

Rada Administracyjna odgrywała dużą rolę w zakresie przygotowywania i stanowienia powszechnie obowiązujących przepisów prawnych. Projekty, które miano wnosić pod obrady izb sejmowych, powinny być uprzednio przedmiotem rozpoznania Rady, przy wspóludziale OZRS. Wprawdzie dla koordynowania prac legislacyjnych tworzono osobne ciała Rady Stanu, jednakże na ogół zastrzegano, że projekty przedstawiane Radzie Stanu musiały być wstępnie rozpatrzone przez zespół ministrów ${ }^{43}$.

40 Ibidem, s. 617.

${ }^{41}$ J. J. Lit a u er, Materialy..., s. XVIII.

${ }^{42}$ Podział przyjęty przez H. I zd e bski e go, Rada Administracyjna Królestwa Polskiego w latach $1815-1830$, Warszawa 1978 , s. 84.

${ }^{43}$ P. S t o e pe 1, Kabinettsordre pruski 1817, Bd. I: Preussisch - Deutscher Gesetz-Codex, wyd. Thiele, Frankfurt a/0 1907, s. 159-161, art. VIII, pkt 1. 
Rada Administracyjna była na mocy Konstytucji obligatoryjnym organem doradczym namiestnika, który wydawał postanowienia w Radzie, w celu wykonania ustawy konstytucyjnej i pełnomocnictwa królewskiego (art. 67, zd. $2 \mathrm{KKP}$ ). Ponadto art. 8 pełnomocnictwa namiestnika ograniczał prawotwórczą działalność Rady Administracyjnej, gdyż projekt przyjęty przez OZRS, który został następnie odrzucony przez namiestnika w Radzie Administracyjnej, musiał być przesłany do monarchy (art. 9).

W trakcie prac nad opracowywaniem księgi II k.c. narodowego, w szczególności przepisów dotyczących prawa rzeczowego, Rada Administracyjna zajmowała dość chwiejne stanowisko. Mianowicie, 16 czerwca 1829 r. Rada pod naciskiem OZRS i KRS podjęła decyzję o zaprzestaniu prac nad ułożeniem całej księgi II k.c. Większość członków Rady Administracyjnej stanęła po stronie obrońców nienaruszalności kodeksu francuskiego i postanowiła zmienić dotychczasowy tryb pracy Deputacji. Następnie 21 listopada $1829 \mathrm{r}^{44}$, pod wpływem woli monarchy, nakazała OZRS prowadzić nadal dyskusję nad projektem księgi II k.c. opracowanej przez Deputację Prawodawczą.

Jednakże Rada Administracyjna pozwoliła Deputacji Prawodawczej, na jej prośbę, od 1 grudnia 1829 r. zająć się opracowywaniem projektów zmian częściowych nad prawem rzeczowym z KN. Rada Administracyjna sama nakreśliła ich plan i rozległość. W związku $\mathrm{z}$ tym, niewiele projektów prawa poddano pod glosowanie na Sejmie roku 1830, co było owocem wcześniejszych decyzji Rady Administracyjnej, podjętych głównie w 1829 r. Nie było wśród nich żadnego ważniejszego projektu, a jedyny, który mial poważniejsze znaczenie, „był nieudolnie zredagowany” - chodzi o prawo o używaniu i użytkowaniu lasów.

3.1. Zgodnie z Konstytucją, Sejm zwyczajny zbieral się co dwa lata w Warszawie, w dniu określonym przez akt konwokacji wydany przez króla. Kadencja Sejmu trwała 30 dni. Sejm mógł być przedłużony, odroczony lub rozwiązany tylko przez króla (art. $87 \mathrm{KKP})^{45}$. Wbrew temu artykułowi zwolano go w ciągu piętnastolecia zaledwie cztery razy: w 1818, 1820, 1825 i $1830 \mathrm{r}$.

${ }^{4}$ RA, t. 17, s. 592-593. Wezwanie, by Deputacja Prawodawcza do dnia 1 grudnia 1829 r. złożyła projekt całej księgi II k.c. Po czym czytano odezwę prywatną ministra sekretarza stanu z daty 30 października/11 listopada 1829 r.: polecajacq na mocy ustnego jego cesarsko-królewskiej mość rozkazu, ażeby Rada szczególnqu uwage swoja zwrócila na postepy w wygotowaniu projektów na przyszly Sejm, ażeby odtą $w$ każdym raporcie tygodniowym uczynionq byla $w$ krótkości, wzmianka czy $i$ co $w$ tej mierze zrobiono. Na koniec ażeby skoro tylko, który z projektów do prawa przejdzie przez dyskusje OZRS byl natychmiast na jezyk francuski przetlumaczonym $i$ najaśniejszemu panu przeslanym wraz z powodami oraz protokolami $w$ języku polskim.

${ }^{45}$ Ustawa Konstytucyjna Królestwa Polskiego, DPKP, t. I, nr 1. 
Ciało prawodawcze składało się z Senatu i Izby Poselskiej. W skład Senatu wchodzili czlonkowie rodziny królewskiej (książęta krwi cesarsko-królewskiej), biskupi, wojewodowie i kasztelanowie ${ }^{46}$. Liczba senatorów nie mogła być większa od połowy liczby posłów i deputowanych, tj. 64 (art. 108-109 KKP). W Senacie zasiadało 18 wojewodów i 37 kasztelanów oraz dziewięciu duchownych. Senatorów dożywotnio mianowal król wybierając jednego spośród dwóch przedstawionych przez Senat kandydatów (art. 110 KKP).

W skład Izby Poselskiej wchodziło 128 posłów, z których 77 wybierały sejmiki powiatowe, a 51 deputowanych - zgromadzenia gminne (art. 118 KKP). Ich mandaty trwały sześć lat; co dwa lata następowała wymiana trzeciej części składu Izby. W praktyce rola Izby Poselskiej została zredukowana, gdyż nie brała ona udziału w redagowaniu praw ${ }^{47}$.

Uprawnienia Sejmu w Królestwie Polskim były znacznie szersze niż w dobie Księstwa Warszawskiego, zaś jego kompetencje prawodawcze obejmowały prawo cywilne, karne i administracyjne (bez spraw wojskowych zastrzeżonych art. 38 KKP królowi, a faktycznie należały do wodza naczelnego).

3.2. Zasada równorzędności izb sejmowych znajdowała odbicie w możliwości wnoszenia projektów prawa. Konstytucja Królestwa Polskiego w art. 94 zakreśliła wyraźną granicę działalności Sejmu, mogacego się trudnić tylko przedmiotami należqcymi do jego atrybucji lub wskazanymi w akcie zwolania.

Zasada przyznawała królowi przywilej wyłączności inicjatywy ustawodawczej w zakresie wszelkich praw i uchwal sejmowych. Projekty do praw były układane w Radzie Stanu i przez członków Rady; na rozkaz króla nadawano im bieg prawodawczy. Chociaż obowiązek przygotowywania projektów prawa cywilnego i karnego spoczywał na Komisji Rządowej Sprawiedliwości lub działających w jej imieniu, w latach 1820-1825 i 1825-1830, Deputacji Prawodawczych.

Za zgodą króla projekty mogły być odsyłane do dyskusji najpierw albo do Izby Poselskiej, albo do Senatu (art. $92 \mathrm{KKP}$ ). Król mógł skierować projekt do tej izby, w której spodziewał się mniejszej opozycji bądź pełnego poparcia. Jedyne ograniczenie dotyczyło rozpatrywania projektów sejmowych oraz projektów prawa finansowego, które musiały być wniesione najpierw do Izby Poselskiej.

Projekt prawa przyjetty $w$ jednej $z$ izb nie mógł być zmieniony przez drugą izbę. Każda $z$ nich mogła go tylko przyjąć lub odrzucić w całości (art. $103 \mathrm{KKP}$ ). Zmiany do projektu wprowadzać mogła wyłącznie Rada

${ }^{46}$ Senatorowie Ksiestwa Warszawskiego i Królestwa Kongresowego 1807-1815-1830, oprac.

A. Boniecki, S. Cieszkowski, Warszawa 1891, s. 14.

${ }^{47}$ W. M. Kozłowski, Autonomia..., s. 103-105. 
Stanu na podstawie uwag podniesionych $w$ izbie, a przedstawionych przez komisje sejmowe (art. 96, 97, 99, $103 \mathrm{KKP}$ ). W praktyce nie tylko inicjatywa, ale również i redakcja praw została wyłączona z kompetencji Sejmu (art. 99, 103 KKP).

Posiedzenia sejmowe odbywały się w sposób następujący: po ukonstytuowaniu się izb, każda $\mathrm{z}$ nich wybierała po trzy oddzielne komisje. Komisje wybrane przez Senat liczyły po trzech członków, a komisje wybrane przez Izbę Poselską - po pięciu członków (art. $98 \mathrm{KKP}$ ). Porządek odbywania posiedzeń komisji ustalił car Aleksander I w postanowieniu 26 marca 1818 r. Dyskusja nad projektem prawa w komisjach sejmowych nie mogła trwać dhużej niż trzy dni; tyle samo czasu przeznaczono na debatę w poszczególnych izbach.

W głosowaniu tajnym powoływano komisję do: 1) praw skarbowych, 2) prawodawstwa cywilnego i kryminalnego, 3) prawodawstwa organicznego i administracyjnego (art. $98 \mathrm{KKP}$ ). Podczas dyskusji nad prawem tylko członkowie komisji mogli przemawiać posługując się notatkami przez siebie sporządzonymi; pozostali członkowie mogli mówić tylko z pamięci (art. $100 \mathrm{KKP}$ ). Jedynie czlonkowie Rady Stanu, którzy byli senatorami, posłami lub deputowanymi gminnymi, mogli zabierać głos $w$ obu izbach i wnosić własne propozycje zmian (wotować) przy omawianiu projektów rządowych; pozostali czlonkowie Rady Stanu nie posiadali tego drugiego uprawnienia (art. 101 KKP).

Projekty przyjmowane były większością głosów; natomiast, jeżeli głosy dzieliły się po równo, projekt uważany był za przyjęty (art. 102 KKP). Po przyjęciu przez Sejm i Senat, ustawa za pośrednictwem Rady Stanu szla do zatwierdzenia przez króla, który miał prawo veta bezwzględnego, tzn. projekt prawa przezeń nie zatwierdzony upadal (art. 104, 105 KKP). Król zarządzał także promulgację podpisanego przezeń aktu w Dzienniku Prawa Królestwa Polskiego.

$\mathrm{Na}$ mocy art. 90 Konstytucji Królestwa, Sejm miał się naradzać nad wszelkimi projektami dotyczącymi praw cywilnych, kryminalnych lub administracyjnych. Zgodnie z Konstytucją Królestwa Polskiego, przedmiotem decyzji Sejmu miały być nie tylko „prawa administracyjne”, lecz również podstawowe kwestie organizacyjne. Jednakże w praktyce Sejm nie wykonywał swoich uprawnień, gdyż nie przedłożono mu ani jednego projektu „prawa administracyjnego" i tylko raz rozpatrywał projekt nowego statutu organicznego.

W sumie, przez 15 lat konstytucyjnego okresu Królestwa, cztery Sejmy rozpatrywały 23 projekty ustaw, z czego odrzuciły pięć projektów.

Jednym $\mathrm{z}$ większych sukcesów pierwszego Sejmu w Królestwie Polskim, który obradowal od 27 marca do 27 kwietnia 1818 r., było uchwalenie 
prawa hipotecznego ${ }^{48}$. Redaktorem tego projektu był czlonek Komisji Rządowej Sprawiedliwości Antoni Wyczechowski ${ }^{49}$. Projekt ten, po ostrej dyskusji, został uchwalony 26 kwietnia 1818 r. większością 67 głosów, przeciwko 40 .

Kolejny Sejm obradował od 13 września do 15 października $1820 \mathrm{r}^{50}$ Sejm ten zajmowal się tylko dwoma projektami z dziedziny prawa cywilnego, mianowicie: projektem o przedłużeniu moratorium na rok i projektem o warunkach odstąpienia własności prywatnej $\mathrm{z}$ powodu użyteczności publicznej, i obydwa te projekty uchwalił.

Trzeci Sejm Królestwa Polskiego obradował od 1/13 maja $1825 \mathrm{r}^{51}$ do 11 czerwca $1825 \mathrm{r}$. Sejm roku 1825 był jednym z najefektywniejszych jak dotychczas pod względem liczby przedyskutowanych na nim i uchwalonych ustaw $^{52}$. Przedstawiono pięc projektów prawa, tj.:

1) projekt ustanowienia Towarzystwa Kredytowego Ziemskiego,

2) projekt księgi pierwszej kodeksu cywilnego Królestwa Polskiego $O$ osobach,

3) projekt $O$ przywilejach $i$ hipotekach zmieniajacy prawo hipoteczne z $1818 r^{53}$,

4) projekt zmiany art. 530 k.c. dotyczący prawa wykupu czynszu wieczystego $(, \text { wiecznego") })^{54} \mathrm{i}$

5) projekt obostrzenia kar na podpalaczy.

Z projektów przygotowanych przez Deputację Prawodawczą i przedstawionych Sejmowi, po otrzymaniu sankcji, moc prawa zyskały następujące ustawy: księga I Kodeksu Cywilnego Królestwa Polskiego ${ }^{55}$ oraz prawo zmieniające przepis art. 530 ksiegi II KN o czynszach wieczystych. Kodeks francuski dawał możliwość wykupu takich ciężarów, ale przepis ten był sprzeczny ze znanym w naszym kraju erbpachtem. Ustawa sejmowa wprowadzała zasadę, iż art. 530 kodeksu francuskiego nie będzie się stosowało do czynszów lub dzierżaw wieczystych, jeżeli możliwość ich wykupu nie była wyraźnie umownie zastrzeżona. Przyjęto ponadto prawo o przywilejach i hipotekach wraz z przepisami intertemporalnymi oraz księgę I i II Kodeksu Karzącego.

48 J. J. L i t a e r, Memorial J.W. Bandtkiego o prawie hipotecznym z roku 1818, Warszawa 1915 , s. 17; także J. Mazurkiewicz, Uwagi o roli ksiag $i$ akt hipoteki polskiej $z 1818$ i 1825 r., "Czasopismo Prawno-Historyczne" [dalej: CPH] 1953, t. 5, s. 148 i n.

49 Obraz Królestwa Polskiego..., t. I, s. 50, przyp. nr 78. Zob. K. Wł. Wójcick i, Wyczechowski Antoni, [w:] Encyklopedia Powszechna, t. 28, wyd. S. Orgelbranda, Warszawa 1868 , s. 8.

so Dziennik posiedzeń Izby Poselskiej..., s. 9 i n.

51 RA, t. 12, s. 284-285.

${ }^{52}$ S. A skenazy, Sto lat Zarzqdu w Królestwie Polskiem. 1800-1900, Lwów 1901, s. 28.

${ }^{53}$ K. W1. Wójcicki, Wyczechowski Antoni, s. 8. Jako czlonek KRS wniósł projekt prawa hipotecznego pod obrady Sejmu.

54 DPKP 1825 , t. 9, s. 352.

ss Kodeks Cywilny Królestwa Polskiego, DPKP 1825, t. 10. 
Generalnie wszystkie projekty do praw wniesione na Sejmie roku 1825 zostały przyjęte zdecydowaną większością głosów; tylko jeden projekt $O$ przywilejach $i$ hipotekach zmieniajacy prawo hipoteczne z $1818 \mathrm{r}$. w dniu 1/13 czerwca 1825 r. został przyjęty większością zaledwie czterech głosów ${ }^{56}$.

Ostatni Sejm w Królestwie Polskim obradował w okresie od 24 maja do 28 czerwca 1830 r. O przyjęciu lub odrzuceniu rządowego projektu ustawy decydował układ sil politycznych w Sejmie, a nie merytoryczna jego wartość. Opozycja postanowiła, że nie poprze żadnego projektu rządowego. Na piątym posiedzeniu Izby Poselskiej Władysław Ostrowski oświadczył, że ponieważ prawo wetowania wymaga, przeto on jest za odrzuceniem każdego projektu ${ }^{57}$.

Na Sejm wniesiono tylko te projekty prawa, które nie miały nic wspólnego ze swobodami konstytucyjnymi. Były to ustawy: o używaniu i użytkowaniu lasów, o postępowaniu spadkowym, o włóczęgach i żebrakach, o służebnościach wolnego pastwiska i wrębu oraz o rozwiązaniu małżeństw.

Pierwszy projekt był wielce pożyteczny $\mathrm{z}$ powodu potrzeby prawnego ograniczenia rabunkowego użytkowania lasów, aby nie dopuścić do ich wyniszczania. Zaakceptowano go $w$ komisjach sejmowych, ale odrzucony został przy pełnym posiedzeniu Izby Poselskiej, 11 czerwca 1830 r., z pobudek ubocznych, tj. natury politycznej. Izba w ten sposób zaprotestowała przeciwko wyłączeniu publiczności obrad ${ }^{58}$, zaś dyskusja nie dotyczyla meritum projektu, ale służyła wyrażeniu stanowiska znamionującego niechęć opinii publicznej. Projekt ten zostal odrzucony stosunkiem 90 głosów przeciw do 28 za, pomimo że posiadał poparcie posłów opozycyjnych, $\mathrm{m}$. in. Gustawa Małachowskiego, Antoniego Ostrowskiego, Konstantego Świdzińskiego i Franciszka Wolowskiego ${ }^{59}$.

Drugi projekt $O$ postepowaniu spadkowym został przyjęty większością głosów $112 \mathrm{za}$, przeciw 10, a trzeci z projektów $O$ wlóczegaach, tulaczach $i$ żebrakach, zostal przyjęty 72 głosami, przeciwko $48^{60}$. Przy dyskusji czwartego projektu ustaw $O$ slużebnościach wolnego pastwiska $i$ wrębu w dniach 18 i 19 czerwca 1830 r. ujawnil się wśród posłów zupełny brak rozeznania co do faktycznych potrzeb ekonomicznych Królestwa. Pomimo

${ }^{56}$ DPKP 1825, t. 9, s. 355 i n. Zob. H. Wójcikiewicz, Prawo hipoteczne Królestwa Polskiego, Wrocław 1967, s. 12.

57 Zob. Diariusz Sejmu z r. 1830-1831, t. I, wyd. M. Rostworowski, Kraków 1907-1912, s. 93 i n.; także F. Skarbek, Dzieje Polski. Królestwo Polskie, cz. II, Poznań 1877, s. 280.

${ }^{58} \mathrm{H}$. Gry n w a ser, Pisma, t. I, s. 161.

59 O rodzinie Wołowskich bliżej W. W it k ow sk i, Aleksander This $i$ Jan Kanty Wolowski. Wybitni prawnicy Królestwa Polskiego, Lublin 2001, s. 46.

${ }^{60}$ Obraz Królestwa Polskiego..., t. I, przedstawione na posiedzeniu Sejmu dnia 29 V $1830 \mathrm{r}$., s. 287, przyp. 66, czytamy: Sprawy zebractwa i tulactwa w kraju wielokrotnie wnoszone byly do Rady Administracyjnej (RA 10, s. 47, 53, 88; t. 11, s. 52; t. 17, s. 301, 617; t. 18, s. 10 , 220, 254, 276). 
dużej potrzeby tego prawa i niepodważalnej jego użyteczności Radzie Stanu zarzucono przede wszystkim lekceważenie Sejmu z powodu wnoszenia tak mało znaczących projektów. Usiłowano ten projekt odrzucić, aby okazać królowi i narodowi, że Sejm oczekuje ważniejszych praw ${ }^{61}$. Następnie poważnie go zmieniono w komisjach sejmowych, i pomimo głosów opozycji, projekt ten przeszedł większością 82 głosów, przy 30 przeciwnych. Z kolei ostatni projekt dotyczył osobowego prawa małżeńskiego; odrzucono go 93 głosami, za głosowało tylko 22 posłów ${ }^{62}$.

4. Szczególne znaczenie na polu prawodawczym miała Komisja Rządowa Sprawiedliwości Królestwa Polskiego. Zakres jej dzialania nie odbiegał w zasadzie od przeciętnego zakresu działania odpowiadających jej organów innych ówczesnych państw ${ }^{63}$; należało do niego przygotowywanie projektów ustaw cywilnych i karnych ${ }^{64}$, a więc w znacznej mierze Komisja ta przejęła kompetencje Ministra Sprawiedliwości z czasów Księstwa Warszawskiego. Stała też na czele administracji sądownictwa. Z założenia KRS miała być wydziałem wykonawczym Sądu Najwyższej Instancji, skutkiem czego jej członkowie nie weszli z urzędu w skład Rady Stanu ${ }^{65}$. Jednakże w praktyce dość szybko upodobniła się do pozostałych naczelnych organów Królestwa Polskiego.

Komisja Rządowa Sprawiedliwości $\mathrm{z}$ ministrem na czele, będącym jednocześnie członkiem Rady Administracyjnej, nie tylko nie stała się mniejszym kompletem Sądu Najwyższej Instancji, ale uzyskała odrębną i silną pozycję w zarządzie sprawiedliwości. Wyrazem tego była rozdzielność personalna między Sądem Najwyższej Instancji a Komisją Rządową Sprawiedliwości.

Członkowie KRS byli wybierani spomiędzy członków Sądu Najwyższej Instancji; w jej składzie znaleźli się członkowie Sądu Najwyższej Instancji: M. Woźnicki, A. Wyczechowski i W. Ilnicki ${ }^{66}$. Na czele Komisji (resortu sprawiedliwości), zgodnie $\mathrm{z}$ art. $76 \mathrm{KKP}$ stał minister nominowany przez monarchę na przedstawienie namiestnika (art. 41 i 69 Konstytucji i 26 Statutu

${ }^{61}$ S. A sken azy, Sto lat Zarzqdu..., s. 29.

${ }_{62}$ M. Mante ufflowa, Grabowski Tomasz, [w:] Polski slownik biograficzny [dalej: PSB] 1960 , t. 8/4, z. 39, s. 513-514. Wśród popierających projekt autorstwa Franciszka K. Potockiego był ówczesny senator-kasztelan Tomasz Grabowski.

${ }_{63}$ W. Witk ow sk i, Komisja Rzqdowa Sprawiedliwości w Królestwie Polskim 1815-1876, Lublin 1986, s. 16 i n.

${ }^{64}$ Zbiór Przepisów Administracyjnych Królestwa Polskiego, Warszawa 1866-1868, t. II, s. 151-169, art. 11, Statut Organiczny Komisji Rządowych z dnia 17 października $1816 \mathrm{r}$.

${ }^{65}$ H. I zdebski, Kolegialność w Komisjach Rzqdowych Królestwa Polskiego w latach 1815-1830, CPH 1971, t. XXIII, z. 1, s. 69-100.

${ }^{66}$ W. W it k ow sk i, Komisja..., s. 24. 
Organicznego). W Królestwie ${ }^{67}$ funkcje ministra pełnili: w latach 1815 (1 XII) - 1816 (1 V) - Tomasz Wawrzecki ${ }^{68}$, po nim - senator wojewoda Walenty Sobolewski, najpierw jako zastępca (1 V 1816-5/17 X 1816), a później jako minister (aż do 15 XI 1819 r.) $)^{69}$, następnie krótko w latach 1819 (15 XI) - 1920 (wiosna) - Franciszek Węgleński ${ }^{70}$, i w okresie $1820(10 \mathrm{~V})-1824$ (13 XI) - Marcin Badeni ${ }^{71}$. W latach 1824 (listopad) - 1825 (1/13 VI) stanowisko ministra nie było obsadzone, a obowiązki pełnił wiceminister Michał Woźnic$\mathrm{ki}^{72}$. Bezpośrednio po nim stanowisko ministerialne powierzono b. ministrowi sekretarzowi stanu Ignacemu Sobolewskiemu (1/13 VI 1825 - 8 XII $1830^{73}$.

Poza przepisami normującymi działanie Komisji Rządowej Sprawiedliwości, o jej faktycznym funkcjonowaniu decydowała zarówno osobowość każdego $\mathrm{z}$ ministrów sprawiedliwości, jak i charyzma poszczególnych członków Komisji. Wyrazem tego było chociażby Wewnętrzne Urzqdzenie Komisji Rzqdowej Sprawiedliwości z 20 lutego 1817 r., które odzwierciedlało, jak według ministra W. Sobolewskiego przepisy te miały funkcjonować.

$\mathrm{Z}$ przewidywanych trzech posiedzeń Komisji tygodniowo na decydowanie o zagadnieniach ,naradczych”, do których zaliczano m. in. prace nad projektami praw i instrukcjami, przeznaczono tylko jedno - czwartkowe. Ponadto czas posiedzeń wynosił cztery godziny, a oprócz tego, iż radcy podawali wnioski natury ogólnej, dotyczące $\mathrm{m}$. in. prawodawstwa, minister przedstawiał informację o czynnościach organów rządowych. Prace projektodawcze były prowadzone w drodze kolegialnej.

Członkowie Komisji, łącznie z ministrem, odbywali wspólne konferencje z członkami innych komisji, celem wypracowania w kwestiach spornych wspólnych stanowisk. Tak też dyskutowano np. w 1829 r. z czlonkami Komisji Rządowej Wyznań Religijnych i Oświecenia Publicznego na temat prawa małżeńskiego.

W kwestiach politycznych i personalnych stanowisko ministra i członków KRS było zazwyczaj zgodne. Przy częstych zmianach personalnych urzędu ministra i przy stabilnym składzie członków Komisji, którzy w dodatku byli znakomitymi znawcami prawa, to ci ostatni mieli w kolegium więcej do powiedzenia niż minister. Ton $w$ funkcjonowaniu Komisji nadawali w szczególności $\mathbf{M}$. Woźnicki i A. Wyczechowski, i to nie tylko przy czynnościach legislacyjnych ${ }^{74}$.

\footnotetext{
${ }^{67}$ Senatorowie Ksiestwa Warszawskiego..., s. 14.

${ }_{68}$ W. Witk ow sk i, Komisja..., s. 32-34.

69 Ibidem, s. 34-35.

70 Ibidem, s. 35.

71 Ibidem, s. 35-37; także M. M el o c h, Badeni Marcin, PSB 1935, t. 1/1, z. 1, s. 207-208.

72 W. Witk ow ski, Komisja..., s. 37-38.

${ }^{n}$ Ibidem, s. 38-39. Formalnie nigdy ze stanowiska tego nie został odwolany, ale w drugim tygodniu powstania listopadowego zastąpił go Bonawentura Niemojowski.

${ }^{74}$ W. W it k ow ski, Komisja..., s. 112--114.
} 
Należy nadmienić, iż w toku prac prawodawczych nad zmianą księgi II KN dotyczącej prawa rzeczowego czołową rolę odegrał A. Wyczechowski. Działał on zarówno w KRS i wpływał na decyzje tego gremium, jak również jako członek Deputacji Prawodawczych - powoływanych do zmian Kodeksu Napoleona. Ponadto KRS miała wpływ na bieg prac prawodawczych na podstawie różnych przepisów szczególnych nie dotyczących bezpośrednio jej funkcjonowania, a wydawanych $w$ trakcie prowadzonych prac nad prawem rzeczowym. Mianowicie, 18 września 1817 r. namiestnik zobowiązal KRS do przygotowania dla każdej z Deputacji stosownej „cząstkowej” instrukcji. Od tego momentu Komisja miała pełnić funkcje nadzorczą i koordynującą pracę poszczególnych Deputacji, w tym deputacji pracującej nad prawem rzeczowym ${ }^{75}$.

Ponadto, wobec zbliżającego się terminu zwołania Sejmu, na którym miały być przedstawione projekty praw, namiestnik, na wniosek KRS, 4 października 1817 r. ${ }^{76}$ powołał 8-osobową Komisję Prawodawczą. Wcześniej KRS skwapliwie wykorzystała okazję i 18 września 1817 r. zaproponowała namiestnikowi na członków Deputacji ludzi sobie oddanych i przeważnie w niej zatrudnionych, ponieważ chciała mieć wpływ na prace legislacyjne.

Komisja Prawodawcza składała się $\mathrm{z}$ trzech Deputacji: 1) do zmian niektórych przepisów KN (Wincenty Grzymała, Michał Woźnicki i Antoni Wyczechowski); 2) do opracowania procedury sądowej cywilnej (Franciszek Grabowski) $)^{77}$; 3) do opracowania kodeksu kryminalnego materialnego i procesowego (Wincenty Ilnicki, Onufry Grykolewski i Franciszek Ksawery

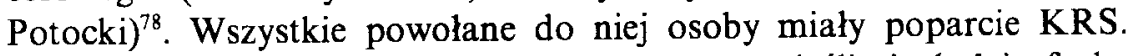

W ten sposób w Komisji Prawodawczej znaleźli się ludzie fachowi, bo minister sprawiedliwości Walenty Sobolewski, naczelnicy wydziałów ministerialnych: A. Wyczechowski, M. Woźnicki i W. Ilnicki, a ponadto radcy stanu nadzwyczajni i członkowie Komisji Rządowej Sprawiedliwości zarazem: sędzia najwyższy (1817 r.) F. K. Potocki ${ }^{79}$ i O. Grykolewski (pełnił także funkcję prezesa sądu kryminalnego województwa krakowskiego i sandomierskiego).

${ }^{75}$ RA, t. 5, s. 148: Do ustanowienia tych wszystkich komisjów pojedynczo lub w kilku razem przedmiotach, Komisja przygotuje projekta do postanowienia wraz ze stosowna do kaźdej materii instrukcja, prócz tego starać się będzie, aby projekt organizacji sqqdownictwa konstytucyjnego już ukonczony i przez Deputacje Komisji odeslany jak najpredzej do dyskusji Rady Stanu mógl być wniesionym. Zawezwie wyznaczonq Deputacje do przejrzenia procedury kryminalnej oraz, ażeby prace swoje, ile możności starala sie ukończyć.

${ }^{76}$ Obraz Królestwa Polskiego..., s. 48-49.

7 M. Manteufflowa, Grabowski Franciszek, PSB 1960, t. 8/4, z. 39, s. 491; także H. Gry nwase r, Niedoszly polski kodeks postepowania cywilnego (1820), „Kwartalnik Prawa Cywilnego i Karnego" 1918, t. I, s. 89.

${ }_{78}^{7}$ RA, t. 5, s. 158; także H. G ry n wa ser, Pisma, t. I, s. 91, przyp. 2.

${ }^{79}$ W. So bocińsk i, Potocki Franciszek Ksawery h. Lubicz, PSB 1984, t. 28/1, z. 116, s. 88. 
Zgodnie $z$ postanowieniem z 4 października 1817 r., projekty prawodawcze przygotowane przez każdą z Deputacji miały być przedstawione na ogólnym posiedzeniu KRS, w celu dyskusji nad nimi i dokonania odpowiednich korekt w „tworzeniu prawa jednolitego". Następnie projekty te miały być przedyskutowane w Radzie Stanu; dla sprawniejszego przebiegu dyskusji minister sprawiedliwości mial za zadanie przewodniczyć na posiedzeniach $\mathrm{KRS}^{80}$. Jednakże pośpiech zdecydował o tym, że Komisja Prawodawcza w praktyce odstapiła od takiego sposobu redagowania praw; przede wszystkim nie był ściśle przestrzegany wymóg kolegialności. Projekty poszczególnych redaktorów formalnie tylko lub wcale nie były rozpatrywane na posiedzeniach „deputacyjnych i gremialnych”, ale wprost kierowano je do Rady Stanu, z pominięciem KRS, gdzie redaktorzy sami je przedstawiali i bronili. W zasadzie tylko dwa najważniejsze projekty prawa - tj. hipoteczne i małżeńskie - poprzedzone zostały uprzednim przedstawieniem $i$ uchwaleniem zasad w KRS.

Redaktorem prawa hipotecznego ${ }^{81}$ uchwalonego przez Sejm w $1818 \mathrm{r}$. był członek KRS - A. Wyczechowski ${ }^{82}$. Projekt ten po ostrej dyskusji został uchwalony $26 \mathrm{kwietnia} 1818 \mathrm{r}$. większością 67 głosów, przeciwko 40.

Tak więc KRS od początku prac legislacyjnych nad prawem rzeczowym uzyskała wpływ na ich tok jako organ władzy, zaś poszczególni jej członkowie weszli w skład gremiów opracowujących pojedyncze projekty prawodawcze.

Wkrótce po zakończeniu obrad Sejmu roku $1818 \mathrm{r}$. KRS przedstawiła własny projekt prac nad kodeksem cywilnym narodowym. Wynikało z niego, że nowa komisja miała być kontynuacją dotychczasowej Komisji Prawodawczej.

Redaktorzy w pracach kodyfikacyjnych podlegali ciąglej ingerencji ze strony KRS, której co miesiąc mieli przedstawiać raport o postępie prac ${ }^{83}$. Ten rodzaj „kurateli” nad redaktorami był powodem licznych spięć między nimi a KRS o kształt prac prawodawczych, zwłaszcza prawa cywilnego i procedury cywilnej.

Komisja Rządowa Sprawiedliwości miała decydujący wpływ na ostateczny los prac prawodawczych prowadzonych przez A. Bieńkowskiego, aż do roku $1820^{84}$, jak również na losy opracowanej przez Deputację Prawodawczą w latach 1825-1830 księgi II k.c. narodowego. KRS pragnęła utrzymać w Królestwie Polskim Kodeks Napoleona jako prawo obowiązujące, doko-

${ }^{80}$ RA, t. 5, s. 159 , art. 6 .

${ }_{81}$ J. J. Lit a u er, Memorial J. W. Bandtkiego..., s. 17; także J. M a zu rki iewicz, Uwagi o roli ksiqg $i$ akt hipoteki polskiej z 1818 i 1825 r., CPH 1953, t. 5, s. 148 i n.

${ }^{82}$ Obraz Królestwa Polskiego..., t. I, s. 50, przyp. 78. Zob. K. Wł. W ó jci ck i, Wyczechowski Antoni, s. 8.

${ }^{83}$ H. Grynwaser, Pisma, t. I, s. 167

${ }^{84}$ Ibidem, s. 124. 
nując w nim tylko drobnych zmian wynikających z panujących w Królestwie stosunków społecznych i gospodarczych ${ }^{85}$. Dlatego projekt księgi II k.c. narodowego nigdy nie wszedł $w$ życie, a w jego miejsce opracowano pośpiesznie projekty częściowe prawa rzeczowego w Kodeksie Napoleona, takie jak: o własności podzielonej, o używaniu i użytkowaniu lasów oraz o służebnościach wolnego pastwiska i wrębu.

5. W okresie od 1815 do $1830 \mathrm{r}$. tok prac prawodawczych ulegal zmianom, ponieważ wskutek braku czasu Komisji Rządowej Sprawiedliwości tworzono przed Sejmami lat 1818,1825 i 1830 r. osobne ciala legislacyjne (Komisji i Deputacji Prawodawczych). Komisja Prawodawcza pracująca w latach 1817-1818 była ściśle związana z KRS, do której miało należeć w praktyce przygotowanie projektów praw, zgodnie ze Statutem Rady Stanu. Ostatecznie Komisja Prawodawcza została rozwiązana reskryptem namiestnika z dnia 11 sierpnia $1818 \mathrm{r}^{86}$

Związek obu Deputacji Prawodawczych działających w latach 1820-1825 i $1825-1830$ z KRS i z OZRS był dość luźny. Deputacje te miały znamiona szczególnych organów państwowych; tworzone były na czas określony, na mocy decyzji monarszych, a w ich skład wchodzili w pierwszej kolejności wydelegowani członkowie Sejmu oraz Rady Stanu i Komisji Rządowej Sprawiedliwości, a także osoby spoza tych organów ${ }^{87}$.

Drugiej Deputacji udało się uzyskać znaczną samodzielność. Przygotowany przez nią projekt księgi II k.c. narodowego zasadniczo odbiegał od przepisów obowiązującego w Królestwie KN, co było przyczyną konfliktu między Deputacją a Komisją Rządową Sprawiedliwości i Ogólnym Zgromadzeniem Rady Stanu - przekonanymi o potrzebie utrzymania KN. Ponadto prace nad II księga k.c. dawały Deputacji większe możliwości nowatorskich rozwiązań niż prace nad księgą pierwszą. Tym bardziej że księga II KN od początku była krytykowana w Królestwie, gdyż zawarte w niej rozwiązania nie przystawały do kraju o niższej kulturze gospodarczej i społecznej, szczególnie w dziedzinie stosunków własnościowych i dzierżawnych.

Ogólne Zgromadzenie Rady Stanu wysuwało wobec projektu Deputacji także zastrzeżenia formalne; twierdziło bowiem, że zgodnie ze Statutem Rady Stanu, jedynie komisje rządowe miały prawo inicjowania biegu procesu legislacyjnego. Natomiast Deputacje - jej zdaniem - można bylo określić jako delegacje pewnej ilości osób z prawem obeznanych, które król

${ }^{85}$ Obraz Królestwa Polskiego..., t. I, s. 49.

${ }^{86}$ RA, t. 6, s. 312-314.

${ }^{87}$ RA, t. 5, s. 159; t. 6, s. 314; H. G r y nw a se r, Kodeks Napoleona w Polsce. Królestwo Kongresowe, Warszawa 1918, s. 51 i n; W. Sobociński, Rozwój ustawodawstwa cywilnego w Królestwie Polskim $i w$ Rosji do rosyjskiej reformy sqadowej. (Zarys historyczno-porównawczy), Lublin 1965, s. $124 \mathrm{i} \mathrm{n}$. 
przeznaczyl Komisji Rzqdowej Sprawiedliwości ku pomocy w przygotowaniu projektów do prawa ${ }^{88}$.

Spór o status Deputacji Prawodawczej skończył się nie tylko czasowym zawieszeniem przez Radę Administracyjną dyskusji nad projektem księgi II k.c. narodowego, bowiem Izba Poselska w 1830 r. uchwaliła petycje o zniesieniu Deputacji Prawodawczej $\mathrm{z}$ powodu jej niekonstytucyjności i kosztowności ${ }^{89}$. Konflikt Deputacji z Ogólnym Zgromadzeniem Rady Stanu i petycja Izby zmusily Radę Administracyjną do całościowego przedyskutowania problemu przygotowywania ,praw" ${ }^{90} .16$ lipca $1830 \mathrm{r}$. większość członków Rady Administracyjnej była zdania, iż Deputacja, o ile miałaby dalej istnieć, powinna zostać podporządkowana ściśle KRS.

W lipcu $1830 \mathrm{r}$. doszło na tym tle do zanegowania konstytucyjnego statusu dzialania Deputacji. Ostatecznie jednak prace nad narodowym kodeksem cywilnym na wiele lat odsunęło powstanie listopadowe. Po wybuchu powstania Rząd Tymczasowy Królestwa Polskiego jedną z pierwszych swoich uchwal z 10 grudnia 1830 r. ${ }^{91}$ rozwiązal Deputację Prawodawczą - jak podano - ze względów oszczędnościowych i przekazal jej funkcje Komisji Rządowej Sprawiedliwości. Jeszcze w lipcu 1831 r. członek tej Komisji - Aleksander Wielopolski wystąpił z pomysłem gruntownego „ulepszenia prawodawstwa”. Proponował powierzenie tej pracy specjalnej sekcji w KRS, ale jego plan Komisja uznała za ,przedwczesny i nieaktualny" i nie nadała mu dalszego biegu. Po upadku powstania listopadowego prace kodyfikacyjne przyjeły zupelnie inny kierunek i rozmach.

Od Statutu Organicznego z 1832 r. prace przygotowawcze w zakresie prawodawstwa w Królestwie Polskim biegły dwutorowo: w Warszawie i w Petersburgu. Władze carskie podjęły decyzję o zastąpieniu Kodeksu Napoleona nowym prawem, bardziej zbliżonym do prawa rosyjskiego. Próby opracowania i wprowadzenia na ziemiach polskich prawa cywilnego zbliżonego do rosyjskiego trwały prawie przez cały wiek XIX. Tak więc pozostawienie w okresie Królestwa Polskiego Kodeksu Napoleona jako prawa obowiązującego przesądziło o tym, iż jedynym prawem cywilnym zbliżonym do rosyjskiego na tych terenach było prawo o małżeństwie wprowadzone w $1836 \mathrm{r}$.

${ }^{88}$ I Rada Stanu, sygn. 481; OZRS z 15 czerwca, 23 i 27 listopada 1829 r.

${ }^{89}$ I Rada Stanu, t. 256, s. 12: Która gorliwość i pracowitość swojq okazać wlaśnie usiluje $w$ zupelnej zmianie tego, co dotqd istnialo $i$ zagraża krajowi wstrzqśnieciem $w$ stosunkach towarzyskich.

${ }^{90}$ RA, t. 19, s. 609-620, z 16 lipca 1830 r.; $Z$ dziejów Rady Stanu $i$ Rady Administracyjnej. Protokól posiedzenia Rady Administracyjnej $z$ dnia 16 lipca 1830 r., opubl. J. J. Lit a u e r, „Gazeta Sądowa Warszawska” 1917, t. XLV, nr 28 s. 301-303; nr 29, s. 309-310.

${ }^{91}$ H. Grynwaser, Pisma, t. I, s. 163. Uchwała Rządu Tymczasowego z dn. 10 XII 1830 r. Zob. J. Sk ow ronek, Kozlowski Kajetan, PSB 1970, t. 15, s. 14. 
6. Po likwidacji Księstwa Warszawskiego w 1815 r. Kodeks Napoleona pozostal nadal prawem obowiązującym w Królestwie Polskim. Na fali krytyki rozwiązań francuskich krytyce poddano również niektóre instytucje kodeksowe, głównie prawo rzeczowe i osobowe małżeńskie jako nie pasujące do ówczesnego modelu stosunków społeczno-gospodarczych panujących głównie na polskiej wsi. Przez 15 lat rządów konstytucyjnych w Królestwie wiele środowisk społecznych (głównie ziemiaństwo) wysuwało postulaty opracowania wlasnego, narodowego kodeksu cywilnego.

W przeciągu lat 1815-1830 tok prac prawodawczych ulegal zmianom wskutek tworzenia przed Sejmami lat 1818, 1825 i 1830 r. osobnych cial legislacyjnych (Komisji i Deputacji Prawodawczych). Komisja Prawodawcza (1817-1818) była ściśle związana z Komisją Rządową Sprawiedliwości, do której miało należeć $w$ praktyce przygotowanie projektów praw. Z kolei Deputacja Prawodawcza - pierwsza $z$ lat $1820-1825$ i druga $z$ lat $1825-1830$ - miała dość luźny związek z Komisją Rządową Sprawiedliwości i Ogólnym Zgromadzeniem Rady Stanu. Deputacje te były szczególnymi organami państwowymi. Tworzone były na czas określony, na mocy decyzji monarszych; w ich sklad wchodzili wydelegowani członkowie Sejmu, a także Rady Stanu i Komisji Rządowej Sprawiedliwości oraz osoby spoza tych organów.

Drugiej Deputacji udało się uzyskać znaczną samodzielność. Przygotowany przez nią projekt księgi II k.c. narodowego zasadniczo odbiegał od przepisów $\mathrm{KN}$, co było przyczyną konfliktu między Deputacją a Komisją Rządową Sprawiedliwości i Ogólnym Zgromadzeniem Rady Stanu - przekonanymi o potrzebie utrzymania rozwiązań z KN. Podważano formalne uprawnienia Deputacji do inicjowania procesu legislacyjnego. W 1830 r. Izba Poselska uchwalila petycje o zniesieniu Deputacji Prawodawczej z powodu - jak uzasadniano - jej niekonstytucyjności i kosztowności.

Rezultatem prac Deputacji (pierwszej) było uchwalenie w 1825 r. Kodeksu Cywilnego Królestwa Polskiego, który zmieniał I księge KN traktującą o osobowym i majątkowym prawie małżeńskim. Ponadto w tymże roku znowelizowano ustawę hipoteczną z $1818 \mathrm{r}$.

Największe natężenie prac nad zmianą II księgi KN normującej prawo rzeczowe miało miejsce w latach 1825-1830, jednakże wskutek różnicy zdań pomiędzy Komisją Rządową Sprawiedliwości a zależną od niej Deputacją Prawodawczą nie udało się opracować całej księgi narodowego prawa rzeczowego. Efektem pracy Deputacji Prawodawczych były tylko nieliczne zmiany w księdze II KN: mianowicie, ustawą z 13 czerwca $1825 \mathrm{r}$. zmieniono art. $530 \mathrm{KN}$ i pozwolono wlaścicielom ziemskim nadawać grunty rolnikom na zasadzie prawa wieczystego, z zachowaniem dla siebie własności danin. Ponadto niektórzy czlonkowie Rady Stanu uważali, że należy przywrócić wieczyste czynsze gruntowe oraz wlasność podzieloną - dla szybszego rozwoju polskiego rolnictwa. 
W zasadzie od jesieni 1829 r. Deputacja Prawodawcza pracowała nad projektami częściowej nowelizacji prawa rzeczowego z Kodeksu Napoleona; $\mathrm{m}$. in. w czerwcu $1830 \mathrm{r}$. uchwalono prawo $O$ slużebnościach wolnego pastwiska $i$ wrębu.

Wielu ówczesnych polityków i prawników zdawało sobie sprawę, że Kodeks Napoleona nie pasowal do warunków społecznych i ekonomicznych panujących $w$ Królestwie Polskim, oraz że stosunki włościańskie, pomimo obowiązującego prawa francuskiego, nadal rządziły się własnym staropolskim prawem feudalnym. Jednakże należy pamiętać, iż zachowanie mocy obowiązującej kodeksu francuskiego na ziemiach Królestwa Polskiego przesądziło w przyszłości o prawnej odrębności tych terenów w Rosji do czasu odzyskania niepodległości przez Polskę w 1918 r. 